
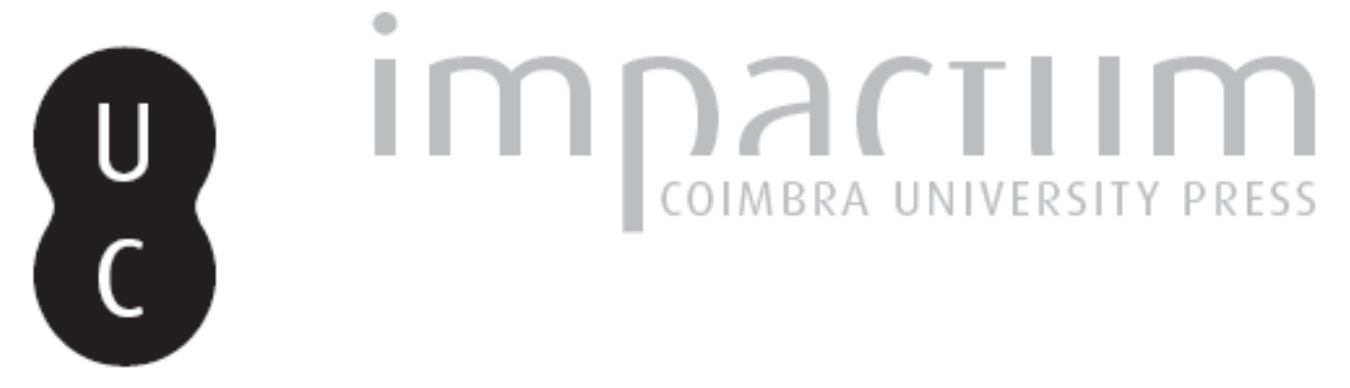

\title{
Um molde de lucerna encontrado em Bracara Augusta
}

\section{Autor(es): Morais, Rui}

Publicado por: Faculdade de Letras da Universidade de Coimbra

URL persistente:

URI:http://hdl.handle.net/10316.2/37670

DOI:

DOI:http://dx.doi.org/10.14195/1647-8657_41_8

Accessed : $\quad$ 26-Apr-2023 03:29:06

A navegação consulta e descarregamento dos títulos inseridos nas Bibliotecas Digitais UC Digitalis, UC Pombalina e UC Impactum, pressupõem a aceitação plena e sem reservas dos Termos e Condições de Uso destas Bibliotecas Digitais, disponíveis em https://digitalis.uc.pt/pt-pt/termos.

Conforme exposto nos referidos Termos e Condições de Uso, o descarregamento de títulos de acesso restrito requer uma licença válida de autorização devendo o utilizador aceder ao(s) documento(s) a partir de um endereço de IP da instituição detentora da supramencionada licença.

Ao utilizador é apenas permitido o descarregamento para uso pessoal, pelo que o emprego do(s) título(s) descarregado(s) para outro fim, designadamente comercial, carece de autorização do respetivo autor ou editor da obra.

Na medida em que todas as obras da UC Digitalis se encontram protegidas pelo Código do Direito de Autor e Direitos Conexos e demais legislação aplicável, toda a cópia, parcial ou total, deste documento, nos casos em que é legalmente admitida, deverá conter ou fazer-se acompanhar por este aviso.

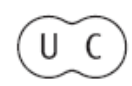




\section{CONIMBRIGA}

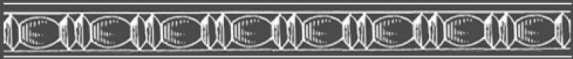

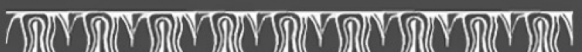
2

INSTITUTO DE ARQUEOLOGIA

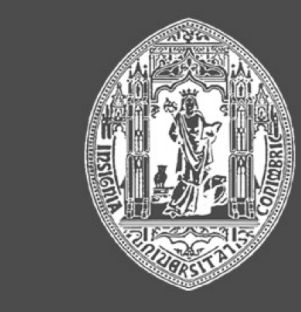

VOLUME XLI - 2002

F A C U L D A E D E LETRAS UNIVERSIDADE DE COIMBRA 
RUI MORAIS

Assistente da Universidade do Minho

UM MOLDE DE LUCERNA ENCONTRADO EM BRACARA AVGVSTA

"Conimbriga" XLI (2002) p. 181-196

RESUMO: Estuda-se a parte superior de um molde bivalve de lucerna de inegável valor estético e ornamental encontrado nas escavações realizadas nas Antigas Cavalariças do Regimento de Braga. O achado deste molde de lucerna, juntamente com outros dois apresentados sob a forma de apêndice, vem mais uma vez testemunhar a presença na antiga cidade da Braga romana de olarias dedicadas à produção de lucernas. Apresenta-se o seu contexto estratigráfico e analisa-se a sua iconografia e respectivo significado e importância da decoração. Propõe-se ainda a reconstituição da metade superior do molde, ausente por fractura, tendo em conta outros paralelos iconográficos conhecidos. Por fim, expõe-se os argumentos a favor de uma cronologia e estilos típicos do período augustano, propondo-se, de acordo com as características estruturais do molde, a sua integração nas lucernas de volutas do tipo Loeschcke I, sub-variante IA, datada de Augusto a Tibério.

Summary: A study of the upper part of a two-piece oil lamp mould, of great aesthetic and ornamental value, found in the excavations done in the Ancient "Cavalariças" of the Regiment of Braga is presented. The finding of this oil lamp mould, together with two other presented in the appendix, is an unquestionable proof of the existence of pottery industries which dedicated themselves to the production of oil lamps in the ancient Roman city of Braga.

Its stratigraphic context is presented as well as the analysis of its iconography and the respective significance and importance of the decoration. The reconstitution of the upper part of the mould, which is broken, is proposed taking in consideration other known iconographic parallels. 
Finally, some arguments in favour of a chronology and typical styles of the Augustan period are exposed and, taking in account the mould structural characteristics, it is proposed that it fits the oil lamps with scrolls, Type Loeschcke I, sub-variant IA, dated from August to Tiberian period. 


\section{UM MOLDE DE LUCERNA ENCONTRADO EM BRACARA AVGVSTA}

Proveniente de escavações efectuadas na cidade de Braga no âmbito do "Projecto de Salvamento de Bracara Augusta", estuda-se um molde de lucerna de inegável valor estético e ornamental. Trata-se da parte superior de um molde bivalve que pela sua dimensão e decoração nos fazem crer que se tratava de um molde para uma lucerna de volutas datável do reinado de Augusto a inícios de Tibério.

O achado deste molde de lucerna, juntamente com dois outros já publicados e que de seguida passaremos a recordar, vem, mais uma vez, testemunhar a presença na antiga cidade da Braga romana de olarias dedicadas à produção de lucernas (Sousa, 1965-66: 165-172; 1969: 309-311; Martins e Delgado, 1989-90: 29; Martins e Delgado, 1989-90: $170-171)^{1}$.

\section{Os dois moldes de lucerna publicados}

A presença dos dois moldes de lucerna acima mencionados já foi dada a conhecer por Rigaud de Sousa em dois artigos distintos (1965-66: 165-172; 1969: 309-311). Encontradas no mesmo local e na mesma altura ${ }^{2}$ estas peças, correspondentes

1 Deve sublinhar-se que parte destas lucernas de fabrico local foram já motivo de estudo por parte de Manuela Delgado, na sua publicação conjunta com Manuela Martins, a propósito das necrópoles de Bracara Augusta (1989-90: 170-71). Neste estudo a autora atribui à grande maioria das lucernas encontradas nas necrópoles uma origem local, provavelmente originária de Braga, e que imitavam os produtos importados ou neles se inspiravam (id., ibidem).

2 Estes dois moldes foram encontrados em 1955 quando da abertura da Rua Santos da Cunha (freguesia de Maximinos, Braga) (Sousa, 1965-66: 168; 1969: 309). Saliente-se, ainda, que neste local foram ainda encontrados vestígios dum forno cerâmico e grande quantidade de argila pronta a ser utilizada (id., 1965-66: 169). 
à parte inferior dos moldes, constituem um conjunto muito homogéneo, quer no fabrico, quer na tipologia ${ }^{3}$.

O primeiro a ser motivo de estudo e publicação, de tonalidade esbranquiçada e muito bem cozido, serviu para fabricar lâmpadas de volutas ${ }^{4}$ (Est. I, 1 e 2). No fundo da face interna do molde encontra-se em negativo a marca retrógada TPERTNVM, atribuída à oficina de Lvcivs Mvnativs e assinada por um dos seu libertos de nome $T[\mathrm{~h}]$ reptvs ( = [LVCIVS] MVN[ATIVS] $T[\mathrm{H}] R E P T[\mathrm{VS}])^{5}$. Segundo Bailey (1980: 98), a oficina-mãe situava-se na Itália Central, nos arredores de Roma, e laborou durante os finais do período flávio até aos inícios do reinado de Antonino 6 .

O segundo molde, apesar das suas maiores dimensões, apresenta as mesmas características do anterior (Est. II, 1 e 2; Est. III, 1 e 2). Infelizmente também se encontra mutilado e desta vez a fractura deu-se exactamente pelo ponto onde devia estar a marca eliminando-a na sua totalidade.

$3 \mathrm{O}$ achado de moldes de lucernas não é um feito demasiado frequente no Império. Na Península Ibérica Mª T. Amaré e V. García Marcos (1994: 284) e D. Bernal Casasola (1995: 149) recompilaram as peças hispânicas. Em Portugal, para além destes exemplares conhecidos para Braga, apenas se registaram, de acordo com a bibliografia consultada, moldes de lucernas em Alcácer do Sal (Viana, 1948: 9-10; fig. 11 e 12), Quinta do Rouxinol (Almada) (Cordeiro, et alii, 1992: 43); Conimbriga (Bairrão, 1952: 29-30, n. ${ }^{\circ}$ 15; Almeida, 1953: 186-87, Est. XLIV, n. ${ }^{\circ}$ 218; Belchior, 1969: 78, n. ${ }^{\circ} 198$, Est. XXIV, 3); Serpa (Beja) (Teixeira e Silva, 1986: 147-152) e Setúbal (Silva e Coelho-Soares, 1980-81: 267-69; 276; 283, Est. V, n. $\left.{ }^{\circ} 45\right)$.

4 Segundo Rigaud de Sousa (1965-66: 169), trata-se da parte inferior de um molde de uma "lucerna de volutas do Tipo Dressel 14, Broneer XXII, British Museum 84, Loeschcke VI, Palol Salellas 8”. O facto de se desconhecer o paradeiro deste molde impede a confirmação desta tipologia. Todavia, a ser verdade, estaríamos perante um molde de lucernas integrável na mais recente tipologia de Bailey, designadamente do Tipo B (ii), datável do período tiberiano a inícios do reinado de Trajano (Bailey, 1980: 153-154; 157-183; Est. 10 a 15, n. $^{\circ} 855$ a 916).

5 À frente das oficinas de L. Munativs conhece-se o nome de outros libertos, designadamente os nomes Adiectvs, Amaranthvs, Philemo, Svccessvs, Restvtvs, Mar., entre outros (Almeida, 1953: 85-86; Pavolini, 1980: 124 ss; id., 1981: 171; Beltrán Lloris, 1994: 190).

6 No território actualmente português a marca deste oleiro encontra os seguintes paralelos: Belchior, 1969, n. ${ }^{\circ}$ 84, 85, 114 e 115; Alarcão e Ponte, 1976, n. ${ }^{\circ}$ 143, 100; Almeida, 1953, n. ${ }^{\circ}$ 63, Est. 33, 158; n. ${ }^{\circ} 73$, Est. 35, 160; n. ${ }^{\circ} 93$, Est. 36, 164; Ribeiro, 1959, n. ${ }^{\circ}$ 21, 94; Maia e Maia, 1997: 140. 
$\mathrm{Na}$ parte inferior dos moldes encontram-se letras profundamente gravadas: no primeiro estão presentes as letras $D O$ numa linha superior e as letras $M I$ por baixo destas; no segundo, dado o estado da fractura, apenas são legíveis as letras $D O$. Em ambos os casos a marca, certamente igual, está incompleta inviabilizando qualquer tentativa de interpretação sobre o seu significado.

\section{O CONTEXTO ESTRATIGRÁFICO DO NOVO MOLDE}

Encontrada nas escavações realizadas nas Antigas Cavalariças do Regimento de Infantaria de Braga, esta peça provém de uma camada (c. 9) de ocupação alto-imperial, entre uma camada de derrube (c. 8) e um solo de terra batida (c. 10) (Fig. 1). As intervenções realizadas neste espaço permitiram identificar estruturas que correspondem a um conjunto de grandes blocos graníticos almofadados (Fig. 2), alguns dos quais sobrepostos, cuja funcionalidade nos é de momento impossível determinar, e que apresentam a particularidade de se encontrarem alinhados segundo os eixos do traçado urbano da cidade, com orientação NO/SE, já determinado como pré-flaviano (Fig. 3). A particularidade destas estruturas reside na circunstância de alguns desses blocos possuírem amplas e profundas valas de implantação sem qualquer espólio associado. Trata-se, aparentemente, de estruturas implantadas em zonas sem ocupação anterior, o que nos leva a admitir um momento muito precoce para a sua construção (Morais, 1997-98a: 69) ${ }^{7}$. baixo:

A leitura estratigráfica do corte Norte é a seguinte, de cima para

c. 1 - Camada de remeximento em tons de cinzento e rosa. Contém elementos de granito e tégula de tipo fino e médio. Camada de ocupação das Antigas Cavalariças do Regimento de Infantaria de Braga.

c. 2 - Terra fina, algo argilosa, grau médio de consolidação e de coloração argilosa.

7 A única excepção a esta situação refere-se ao enchimento para nivelamento da rocha contemporânea ao conjunto de blocos sobrepostos, localizada na zona 54/55, cujo estrato C. 6a forneceu um fragmento de pança de paredes finas, de forma indeterminada, de produção itálica cuja cronologia não ultrapassa o reinado de Augusto (Morais, 1997-98a: 69). 
c. 3 - Terra fina, pouco argilosa, baixo grau de consolidação, coloração castanha clara.

c. 4 - Terra fina, bastante argilosa, grau médio de consolidação, coloração predominantemente rosa escura, aparecendo em espaços acastanhada e rosa-acastanhada. Granulado disperso medianamente e pouco calibrado de granito e tégula. Contém inúmeros elementos de granito e tégula essencialmente de tipo médio, juntamente com alguns de tipo fino (opus signinum). Alguns (poucos) pequenos fragmentos de carvão dispersos. Nível de demolição.

c. 5 - Terra fina, algo argilosa, grau médio de consolidação, coloração cinzenta escura com pequenas manchas acastanhadas e pequenos veios negros (cinzas e carvões). Granulado disperso medianamente e pouco calibrado de granito e tégula. Contém elementos de granito (principalmente) e tégula essencialmente de tipo médio e grosseiro. Pequenos veios de cinzas e carvões, para além de alguns fragmentos isolados. Nível de ocupação.

c. 6 - Terra fina, muito argilosa, bastante consolidada, coloração bege-acastanhada escura com inúmeros veios e pontos de argila bege, rosa, amarelados e acinzentados. Granulado disperso medianamente e muito calibrado de granito (chegando a formar pequenos veios) e tégula. De referir a existência de alguns fragmentos de osso. Contém elementos de granito e tégula essencialmente de tipo fino, assim como alguns pontos de carvão dispersos. Possível solo?

c. 7 - Terra fina, bastante argilosa, grau médio de consolidação, coloração predominantemente castanha clara com inúmeras bolsas castanhas escuras sob e sobre a maior concentração do derrube; existem ainda inúmeras pequenas bolsas de argila rosa e bege nos seus vários tons, por vezes representadas por areão fino e médio (fragmentos de solo?). Granulado disperso medianamente e pouco calibrado de granito. Contém elementos de granito e tégula de tipo fino, médio e grosseiro, com maior concentração na sua base. Um ou outro fragmento de carvão disperso. Camada de derrube.

c. 8 - Terra fina, bastante argilosa, grau médio de consolidação; coloração predominantemente castanha clara com pequenas manchas castanhas escuras e ainda muitíssimos pequenos pontos e bolsas de argila amarelo torrado claro, para além de pequenos veios e bolsas rosa escuro. Granulado disperso medianamente e muito calibrado de granito. Contém elementos de granito e tégula essencialmente de tipo médio. Alguns pequenos pontos de carvão dispersos.

c. 9 - Terra fina, bastante argilosa, grau médio de consolidação, coloração castanha-acinzentada escura com veios cinzentos escuros e negros (cinzas e carvões) e ainda pequenos veios e bolsas arenosas e beges, 
em especial no perfil Norte. Granulado disperso medianamente e pouco calibrado de granito e tégula. Contém alguns elementos de granito e tégula essencialmente de tipo fino e médio, com um ou outro tipo grosseiro à mistura. Inúmeros fragmentos de carvões, chegando a formar grandes veios. Camada de ocupação.

c. 10 - Terra fina, muito argilosa, alto grau de consolidação; coloração variável entre o castanho, bege escuro, rosa acastanhado e ainda uma ou outra pequena bolsa rosa escura. Abundante granulado disperso e muito calibrado de granito, grande parte em decomposição. Contém bastantes elementos de granito e quartzo de tipo fino, juntamente com um ou outro de granito e tégula de tipo médio. Um ou outro pequeno fragmento de carvão. Solo.

c. 11 - Terra batida, algo argilosa, grau médio de consolidação; coloração em tons acastanhados, predominando o escuro, com inúmeros pontos, veios e bolsas de coloração amarelo-claro e bege. Granulado disperso medianamente calibrado de granito e quartzo, juntamente com um ou outro bastante calibrado. Contém bastantes elementos de granito de tipo fino e médio, juntamente com um ou outro de quartzo e tégula de tipo fino. Um ou outro pequeníssimo ponto de carvão. Enchimento para assentamento do solo.

\section{ANÁLISE ICONOGRÁFICA}

Para a análise iconográfica desta peça retomamos a antiga classificação de Loeschcke (1919), actualizada por Bailey (1980), que estabelece cinco grupos principais, a saber: I. Religião e mito; II. Personagens históricas; III. Vida quotidiana; IV. Fauna; V. Plantas e desenhos florais ${ }^{8}$. Dentre estes, apesar do nível de fragmentação da peça e dos motivos decorativos, situámos a peça em estudo no Grupo I.

A decoração da parte superior do molde bivalve, na parte correspondente ao disco (Est. IV, 1 e 2; Est. V, 1 e 2), descreve um espaço doméstico, provavelmente o triclinium, em cujo centro se encontra uma típica e ornamentada mesa romana de três pés ${ }^{9}$. Sobre o tampo da mesa

8 Uma classificação temática mais completa de cenas decorativas sobre discos de lucernas encontra-se em Deonna (1927). Nesta classificação seguimos, todavia, a proposta de Morillo Cerdán (1999: 166) que adoptou as anteriores classificações por apresentarem uma divisão temática mais curta e melhor estruturada.

9 Este tipo de mesas está documentado pelo mobiliário proveniente da cidade de Pompeia (Andrews, 1990: 34) e em várias pinturas murais com a mesma proveniência 
repousam três objectos de baixela romana que identificamos, da esquerda para direita, como sendo um simpunlum de pega vertical plana, um jarro e um copo. A ladear a mesa, duas serpentes ${ }^{10}$, afrontadas, erguidas uma de cada lado. Da serpente do lado esquerdo falta, por fractura, a quase totalidade do corpo. Dela apenas é visível parte da cabeça posicionada de frente.

A restante parte da zona ornamentada está preenchida com a representação de um lectus, vendo-se o pregueado da coberta (numa interpretação mais arrojada poder-se-ia admitir que este pregueado representaria figuras humanas estilizadas e colunata). No canto superior direito do fragmento vê-se parte do que supomos ser o braço com a respectiva mão de uma figura que repousa sobre o lectus.

\section{O SIGNIFICADO E IMPORTÂNCIA DA DECORAÇÃO}

Não se afigura fácil tratar do significado e importância iconográfica deste molde. Efectivamente, na estrutura da composição, ainda que o estilo da decoração seja inspirado em modelos clássicos, não deixa de ser verdade que a sua representação, demasiado esquemática, diriamos mesmo "tosca", não permite trilhar caminhos demasiado afirmativos. Limitamo-nos assim a sugerir uma análise dos motivos decorativos presentes como mero ensaio interpretativo.

- A representação da mesa com três objectos da baixela romana deverá ser interpretada como fazendo parte de uma actividade sacrificial e não uma cena de symposium ou banquete. Para esta hipótese contribui o restante da decoração, designadamente

(Frohlich, 1991: Est. 18, 1; Est. 19, 1; Est. 21, 1 e 2; Est. 29, 3; Est. 37, 1) e de Herculano (Étienne, 1992: 130; 193) e por alguns relevos funerários com cenas de banquete, dos quais destacamos dois documentados em Itália, um proveniente de San Vittorino (Amiternum) (Bandinelli, 1992: 67, fig. 75; 401) e outro de Ancona (id., ibidem: 67, fig. 77; 401).

10 De acordo com a bibliografia disponível para o território actualmente português, a representação em lucernas com a imagem de duas serpentes encontra-se documentada numa lucerna, actualmente no Museu Monográfico de Conímbriga, estudada por diferentes autores (Oleiro, 1952: 33; Est. XII, n. ${ }^{\circ} 23$; Almeida, 1953: 159, Est. XXXV, 69; Belchior, 1969: 50 [102]; Est. XI, n. ${ }^{\circ}$ 4) e numa lucerna vidrada proveniente de Braga (Morillo Cerdán, 1996; Morais, 1997-98b: 167-169; Est. III). 
a representação das serpentes. Afastada parece a hipótese de se tratar de um banquete funerário dado não termos encontrado a representação de serpentes associada a essa iconografia.

- A utilização da serpente no mundo romano tinha como função primordial a representação simbólica do "genius loci" e da imortalidade (Ronchetti, 1922: 895). No caso presente, a figuração das duas serpentes pode simbolizar, respectivamente, o génio do paterfamilias e o da materfamilias (Juno Lucina) que, confundidos com os espíritos dos antepassados, velam pela casa e pela descendência (Grenier, 1927: 467-8; Fredouille, 1999: 70). A representação de serpentes associadas a este tipo de iconografia pode ser testemunhada em diferentes e abundantes pinturas murais das cidades do Vesúvio, particularmente da cidade de Pompeia, em nichos ou pequenas capelas de frontão triangular, designadas por lararium, destinadas a albergar a imagem pintada ou estatueta do lar familiaris, ou mesmo, a partir de Augusto, o génio de Augusto (Genius Augusti) (vid., por exemplo, Frohlich, 1991: Est. 29, 3; Est. 37, 1) (Est. VI).

\section{A(s) figura (s) ausente(s): uma hipótese interpretativa}

Por fractura, falta a metade superior deste molde de lucerna. Para preencher o espaço que falta propomos dois diferentes tipos de leitura. Estas hipóteses baseiam-se, antes de mais, pela aceitação de que sobre o lectus estaria uma ou mais figuras reclinadas, podendo desta forma tratar-se de um par homem / mulher ou da representação do génio do lar familiaris ou mesmo do Genivs Augusti.

- Para a primeira hipótese estaríamos perante um repertório que representava um homem e uma mulher em intimidades sexuais, repertório esse adoptado pelos artistas do período augustano a partir de temas reais ou imaginários utilizados no período helenístico ${ }^{11}$. Desta feita a representação iconográfica de um par na cama figurava quer em pinturas murais (Est. VII), painéis de mosaicos, ou objectos

11 No seu conjunto, toda a evidência para a construção do sexo e género nos trezentos anos que vão do período de Alexandre o Magno a Augusto indica uma tradição extremamente rica, quer visual, quer textual, para os artistas romanos do período de Augusto (Clarke, 2001: 55). 
de luxo - tais como gemas, baixelas de prata e vidros policromados - quer em objectos de uso quotidiano, como moedas, spintriae, espelhos de bronze, estatuetas de terra-cota, sigillata de tipo itálica (especialmente aretina), cerâmica comum, ou, mais frequentemente, lucernas ${ }^{12}$.

- A segunda hipótese, seguramente mais tentadora, integra a totalidade da iconografia representada num contexto e atmosfera de sacralidade. De facto, como já sublinhámos, a presença sobre a mesa da baixela de tipo sacrificial, juntamente com a presença das serpentes, leva-nos a crer que a figura que estaria reclinada sobre o lectus se tratasse do génio do lar familiaris ou mesmo do Genivs Augusti. Este é frequentemente representado por um jovem homem com uma coroa de louro na cabeça, dançando sobre um pé ou reclinado num lectus, vestindo uma túnica curta, e possuindo como atributos o corno da abundância e uma pátera. Esta iconografia, que provavelmente estaria representada no molde de lucerna em estudo, encontra paralelos específicos em duas pinturas murais provenientes de Pompeia, uma da "Casa del Larario del Sarnio" (Frohlich, 1991: 65; 91; 208; 263-264; Est. 29,3 ) e outra (Est. VIII), a partir de uma reconstituição em desenho, do conhecido "Hospitium e Thermolium" (id. ibidem: 273; Est. 37, 1). A ser considerada esta hipótese para a iconografia deste molde de lucerna, este representava mais um testemunho de que os rituais celebrados em público eram também comemorados e conceptualizados através de imagens, inclusive na arte privada, funcionando como símbolos e idealizações de actividades ritualizadas, e representativa da identidade romana. Neste caso, e como bem acentua Jás Elsner (1998: 36) no seu estudo intitulado "Imperial Rome and Christian Triumph", a arte privada, reflectindo o mundo da vida pública, servia como meio fundamental para identificar, construir e negociar a posição do indivíduo na hierarquia da sociedade romana.

12 A utilização frequente destes e doutros motivos em diferentes suportes vem desta forma corroborar a existência e circulação de livros de desenhos, ou seja e existência de manuais sobre sexo e enciclopédias de catálogos sobre diferentes posições. Uma vez feita cópia destes manuais em objectos do uso quotidiano e de baixo preço, como por exemplo as lucernas, estes serviriam como potenciais modelos de reprodução para os pintores murais e artistas que trabalhavam sobre outros suportes, dada a sua abundância e, naturalmente, menor raridade (Clarke, 2001: 115; 245-247). 


\section{CRONOLOGIA E ESTILO}

Os elementos para definir os limites cronológicos da peça em estudo são relativamente poucos, e não de fácil interpretação. Em todo o caso, esta peça possui componentes estruturais que possibilitam uma apreciação de âmbito cronológico e estilístico.

De acordo com essas componentes estruturais, pensamos estar perante um molde de um exemplar utilizado para o fabrico de lucernas de volutas. Morfologicamente diferentes relativamente às últimas variantes de lucernas tardo-republicanas conhecidas, estas caracterizam-se por possuir uma elevada qualidade técnica e artística, que se reflecte no refinamento e na cuidada eleição de novos motivos ornamentais que decoram o disco. Na verdade, a inovação da utilização do molde para o fabrico deste tipo de lucernas vem possibilitar um maior aproveitamento do disco, elevando, desse modo, as suas possibilidades decorativas, cujas dimensões aumentam consideravelmente.

Desta feita, e tendo em conta a natural evolução da forma ao longo do período alto-imperial, Loeschcke (1919: 24-46) estabelece cinco formas distintas (I a V). Dentre estas enquadramos a peça em estudo no tipo de lucernas com rostrum triangular ladeado por volutas enquadradas na denominação genérica de tipo Loeschcke I. O disco de grandes dimensões, com cerca de $127 \mathrm{~mm}$ de diâmetro, decorado com rebuscadas representações de alto relevo, e a presença neste molde de uma orla estreita com perfil horizontal e reduzido à mínima dimensão, mas sobretudo a presença destacada de molduras de transição, permitem agrupá-lo numa das três sub-variantes estabelecidas por aquele autor (id., ibidem: $24-5$ ). Trata-se da primeira delas - a sub-variante $\mathrm{IA}^{13}$ datada entre o período de Augusto a Tibério (id., ibidem: 29-30) ${ }^{14}$.

De acordo com os dados recentemente recolhidos por Morillo Cerdán, na sua tese de doutoramento sobre lucernas romanas na região

13 A equivalência desta sub-variante para a tipologia de outros autores é a que se segue: Walters, 78-80; Broneer XXII; Ivanyi I; Palol 6A; Goldman XII; Dressel-Lamboglia 9A; Lerat III-2, A; Ponsich II-A, 1; Deneauve IVA; Alarcão e Salete B-I, 1a; Leibundgut V; Bailey A; Amare IV-2, Aa.

14 Em Portugal, de acordo com a bibliografia consultada, os exemplares desta sub-variante apenas se encontram documentados no Museu de Alcácer do Sal (Almeida, 1953: 150-1, Est. XXX, n. ${ }^{\circ}$ 11-13) e no Museu de Conímbriga (Alarcão e Ponte, 1976: 96 , Est. XXIII, n. $\left.{ }^{\circ} 15\right)$. 
setentrional da Península Ibérica, este modelo encontra-se principalmente difundido na Península Itálica, Africa Proconsular, sul da Gália e costa mediterrânica espanhola (1999: 72) ${ }^{15}$.

Para os estabelecimentos setentrionais da Península Ibérica, Morillo Cerdán (id., ibidem: 72-3) regista um total de 59 exemplares, inequivocamente pertencentes a esta sub-variante, distribuídos pelos estabelecimentos de Herrera de Pisuerga (40 exemplares), Astorga (17 exemplares) e León (com apenas um exemplar). Como novidade de repartição geográfica, o autor (id., ibidem: 73) assinala a presença de uma lucerna deste tipo no Castro de Coãna, sublinhando-a como exemplo mais antigo até à data documentado no Norte da Cordilheira Cantábrica.

Neste contexto regional, e a julgar pelos dados estratigráficos disponíveis documentados em Herrera de Pisuerga e Astorga, esta variante, documentada desde o período augustano até ao reinado de Tibério, predomina desde a mudança de era até o ano de 15/20 d. C. (id., ibidem: 73-4). Seguindo ainda as indicações referidas por Morillo Cerdán (id., ibidem: 75) acerca deste mesmo conjunto, é de salientar a presença de apenas duas marcas de oficinas, designadamente uma letra incisa no exemplar único proveniente de Coãna, e uma marca anepígrafa, proveniente de Astorga.

Outro aspecto particularmente interessante referido pelo autor (id., ibidem) para estes exemplares documentados no Norte de Península diz respeito a um conjunto de peças provenientes de Herrera de Pisuerga, que possuem características de fabrico distintas das conhecidas produções importadas, e a existência de peças com superfícies e pastas enegrecidas associadas a acidentes de cozedura, que testemunham seguramente uma produção local; estes dados parece ainda serem corroborados pela existência de uma produção local de lucernas tipo Dressel 4, suas contemporâneas.

Embora seja arriscado pretender adiantar conclusões com base no que acabámos de dizer sobre a produção local deste tipo de lucernas em

15 Segundo a pesquisa bibliográfica efectuada pelo autor (Morillo Cerdán, 1999: 72), na Península Ibérica estas formas estão documentadas em Ampúrias, Museu Arqueológico de Sevilha, Colecção Quintana de Barcelona, Osuna, Museu Arqueológico de Córdova, Museu Arqueológico de Ibiza, Barcelona, Casa da Condessa de Lebrija, Mahón, Bilbilis, Aragão, Segobriga, Can Xamnar (Mataró), Bética, Arcobriga, Tarragona e Múrcia. 
Herrera de Pisuerga, penso que é aceitável propor a existência em $\mathrm{Bra}$ cara Augusta de uma produção local deste tipo de lucernas nas primeiras décadas da existência da cidade. De facto, a análise do molde à lupa binocular revelou uma pasta idêntica à dos outros moldes existentes na cidade, cuja argila parece provir, como já referimos, de áreas de caulinos existentes, entre outras regiões, ao longo da costa Norte de Portugal e região de Ourense.

Sob o ponto de vista artístico esta peça possui uma iconografia singular e de cariz provincial. De facto, apesar da adopção de modelos de nítida inspiração clássica, os motivos estão representados de forma esquemática e artificialmente distorcida, fruto da adaptação local a uma nova linguagem artística e cultural. Nessa medida, as observações anteriormente tecidas sobre o significado e importância iconográfica da decoração valem como propostas para uma classificação estilística que não contrariam, em definitivo, a data conhecida para a produção deste tipo de lucernas.

\section{ALGUMAS CONSIDERAÇÕES FINAIS}

Perante o quadro esboçado sobre a presença de moldes de lucernas em Bracara Augusta, cremos que se pode afirmar, com alguma segurança, a existência de uma produção local de lucernas já a partir dos primeiros tempos de vida da cidade.

Neste ponto devemos salientar, mais uma vez, a importância da peça em estudo dado tratar-se do primeiro molde desta sub-variante de lucernas encontrado na Península. Esta situação não causa nenhuma estranheza se considerarmos a produção deste tipo de lucernas em Herrera de Pisuerga e a produção continuada, em toda a Península, de outros tipos ao longo do período imperial (Morillo Cerdán, 1999: 159$-162 ; 309-327)$.

No que respeita directamente às lucernas de volutas sabemos que em poucas décadas se estendem por toda a bacia do Mediterrâneo, resultante da abertura de uma extensa rede de officinae principais e sucursais, assim como numerosas falsificações fraudulentas, destinadas a suprir a crescente procura de lucernas decoradas (id., ibidem: 163).

A bem ver, a procura gerada pela cidade e o transporte terrestre a grande distância, que implicava um oneroso incremento dos custos, 
foram directamente responsáveis pela produção de lucernas a nível regional e local.

É ainda de notar que em Bracara Augusta - à semelhança de outros estabelecimentos na região setentrional da Península - se tem vindo a documentar a presença de exemplares extrapeninsulares que testemunham a existência de um incipiente tráfego comercial a partir dos portos mediterrânicos. Dentre estes, fazemos destacar pela sua excepcional qualidade duas lucernas vidradas, uma do tipo Loeschcke III e outra do tipo Bailey P iii (Morais, 1997-98b: 165-170). Neste ponto, julgamos que será verosímil supor que a cidade, como capital do conventus bracaraugustanus, poderia ter funcionado como centro redistribuidor de materiais - entre os quais as lucernas - não só para as regiões vizinhas mas também para outras zonas geográficas mais afastadas (Morais, 1998: 81).

\section{BIBLIOGRAFIA}

Alarcão, A. M. e Ponte, S. (1976) - "Les Lampes", Fouilles de Conimbriga, VI (Céramiques diverses et verres), Diffusion E. de Boccard, Paris, 1976, 93-114. AlmeIDA, J. A. F. (1953) - "Introdução ao estudo das lucernas romanas em Portugal", O Arqueólogo Português, Nova série, vol. II (M. N. A. E.), Lisboa, 1953, 5-208. Amare, Ma T. e Garcia Marcos, V. (1994) - "Una producción de lucernas en Asturica Augusta", Zephyrus, XLVII, 1994, 273-285.

Ambrosio, A. d' (1990) - Rediscovering Pompeii, Catalogue, "L'Erma" di BretSCHNEIDER, Roma, 1991, 195-96.

Andrews, I. (1990) - "Pompeia", Historia del mundo para jovenes, Monografias, Akal/Cambridge, Madrid, 1990.

Bailey, D. M. (1980) - A Catalogue of the lamps in the British Museum, 2, Roman Lamps in Italy, British Museum, Londres, 1980.

BAIRRÃo Oleiro, (1952) - Catálogo de lucernas romanas, Museu Machado de Castro, Coimbra, 1952.

BANDinelli, R. B. (1992) - Roma. L'arte romana nel centro del potere. Dalle origini alla fine del II secolo d. C., BUR ARTE, Biblioteca Universale Rizzoli, Milão, 1992.

BelChIOR, C. (1969) - Lucernas romanas de Conimbriga, Museu Monográfico de Conimbriga, Coimbra, 1969.

Beltrán Lloris (1994) - "Artistas y Artesanos en la Antiguedad Clásica", Artistas y Artesanos en la Antiguedad Clásica. Los ceramistas y alfareros en Roma, Cuadernos Emeritenses - 8, Museo Nacional de Arte Romano / Asociación de Amigos del Museo, Mérida, 1994, 160-213. 
Bernal Casasola, D. (1995) - "Tecnologia de manufactura de lucernas en epoca romana: dos elementos de fabricación a molde en la P. Ibérica", Estudis sobre cerámica antiga, Actes del simposi sobre cerámica antiga, Màrius Vendrell-Saz, Trinitat Pradell, Judit Molera i Maite Garcia (ed.), Generalitat de Catalunya, Departament de Cultura, Barcelona, 1995, 147-150.

Clarke, J. R. (2001) - Looking at Lovemaking. Constructions of sexuality in Roman Art 100 B. C. - A. D. 250, University of California Press, Berkeley, 2001.

CoRdeIRO, J. M. et alii (1992) - “Ânforas Lusitanas”, Revista de Arqueología, Madrid, 134, 1992, 36-45.

Deneauve, J. (1969) - Lampes de Carthage, Paris, 1969.

Deona, W. (1927) - "L'ornamentation des lampes romaines", Revue Archéologique, 26, 1927, 233-263.

ElSNER, J. (1998) - "Imperial Rome and Christian Triumph. The Art of the Roman Empire AD 100-450", Oxford History of Art, Oxford University Press, Oxford/New York, 1998.

EnCARnaÇão, J. d' (1987) - "Introdução ao estudo da Epigrafia Latina", Cadernos de Arqueologia e Arte, 1, Instituto de Arqueologia/Faculdade de Letras de Coimbra, Coimbra, 1987.

ÉTIENNE, R. (1991) - Pompei la città sepolta, Universale Electra/Gallimard, 1991.

Fredouille, J.-C. (1999) - Dictionnaire de la Civilisation romaine, Larousse, Paris, 1999, 70.

FroHLICH, T. (1991) - «Lararien-und Fassadenbilder in den Vesuvstadten. Untersuchungen zur Volkstumlichen Pompejanischen Malerei”, Mitteilungen des Deutschen Archaeologischen Instituts, Verlag Philipp Von Zabern, Mainz, 1991.

GrenIER, A. (1927) - El Genio Romano, Barcelona, 1927.

LoEsCHCKE, S. (1919) - Lampen aus Vindonissa, Ein Beitrag zur Geschichte von Vindonissa und des Antiken Beleuchtungwesens, Zurique, 1919.

Maia e MaIA (1997) - Maria Garcia Pereira Maia e Manuel Maia - Lucerna de Santa Bárbara, Núcleo de Arqueologia da Cortiçol, Edição Cortiçol, Castro Verde, 1997.

Martins, M. e Delgado, M. (1989-90) - M. Martins e M. Delgado - "História e Arqueologia de uma cidade em devir: Bracara Augusta", Cadernos de Arqueologia, série II, 6-7, Braga, 1989-90, 11-39.

(1989-90) - As Necrópoles de Bracara Augusta", Cadernos de Arqueologia, série II, 6-7, Braga, 1989-90, 41-186.

MoraIs, R. (1998) - "As ânforas da zona das Carvalheiras. Contribuição para o estudo das ânforas romanas de Bracara Augusta", Cadernos de Arqueologia, Monografias, 8, Braga, 1998.

(1997-98a) - "Importações de cerâmicas finas em Bracara Avgvsta: da fundação até à época flávia”, Cadernos de Arqueologia, série II, 14-15, Braga, 1997-98, 47-97.

(1997-98b) - "Estudo de duas lucernas vidradas de época romana encontradas em Bracara Avgvsta", Cadernos de Arqueologia, série II, 14-15, Braga, 1997$-98,165-170$. 
Morillo Cerdán, A. (1996) - "Lucernas vidriadas de época romana en la península ibérica. Dos ejemplares inéditos depositados en el Museo Arqueológico Nacional de Madrid", AUISEK 2, 1996, 29-44.

(1999) - "Lucernas romanas en la región septentrional de la península ibérica. Contribución al conocimiento de la implantación romana en Hispania”, Monographies instrumentum, 8/2, vol. I e II, Éditions Monique Mergoil, Montagnac, 1999.

PAvolini (1980) - "Le lucerne in terra sigillata africana de esportazione. Proposte di una tipologia", Colloque sur la Céramique Antique (Cartago), Actes, Cartago, 1980, 141-149.

(1981) - "Le lucerne nell'Italia romana", Società romana e produzione schavistica, II: merci, mercati e scambi nel Mediterraneo, Bari-Roma, 1981, 139-184 e $278-288$.

RibeIRo (1959) - "Lucernas romanas de Peroguarda", Arquivo de Beja, XVI, Beja, $1959,79-102$.

Ronchetti, V. G. (1922) - Dizionario Illustrato dei Simboli, Hoepli, Milão, 1922, 895.

Silva, C. T. da S. e Coelho-SoARes, A. (1980-81) - "A praça do Bocage (Setúbal) na época romana. Escavações arqueológicas de 1980”, Setúbal Arqueológica, vols. VI-VII, M. A. E. S. - A. D. S., Setúbal, 1980-81, 249-284.

SousA, J. J. Rigaud de (1965-66) - “Àcerca de um molde de lucerna”, Trabalhos de Antropologia e Etnografia, vol. XX, fasc. 1-2, Porto, 1965-66, 165-172. (1969) - "Novo molde de lucernas aparecido em Braga", Trabalhos de Antropologia e Etnografia, vol. XXI, Porto, 1969, 309-311.

Teixeira, A. J. M. e Silva, R. A. M. B. (1986) - "Molde de lucerna do sítio do Nicolau”, Arquivo de Beja, vol. III - 2ª série, Beja, 1986, 147-152.

ViAnA, A. (1948) - "Alcácer do Sal: Museu Arqueológico e colecção particular”, Arquivo de Beja, vol. V - 1aㅡ série, Beja, 9, 1948, 12-3.

ZANKer, P. (1987) - Augusto e il potere delle immagini, Giulio Einaudi editore, Torino, 1987. 


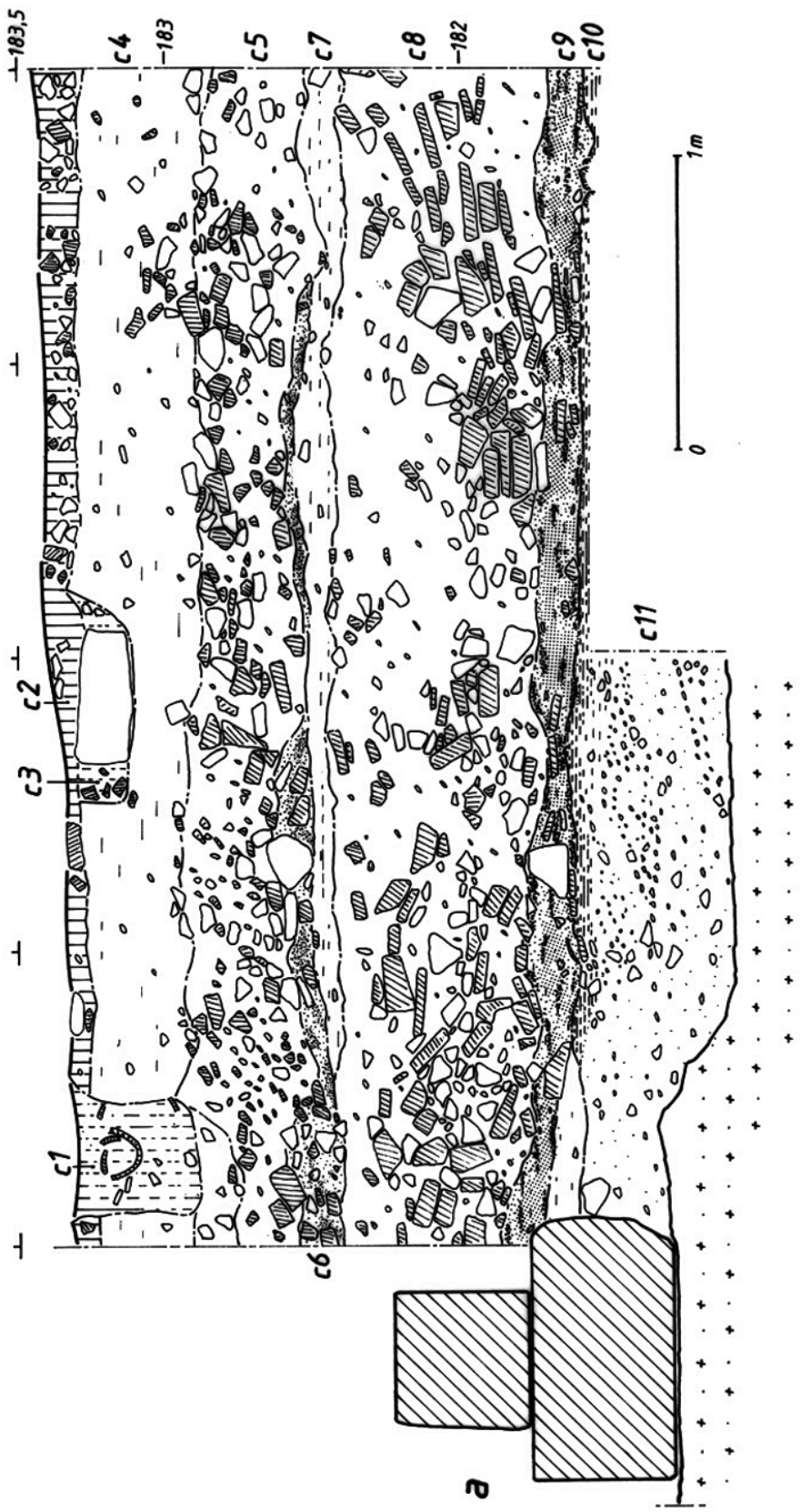

FIG. 1 


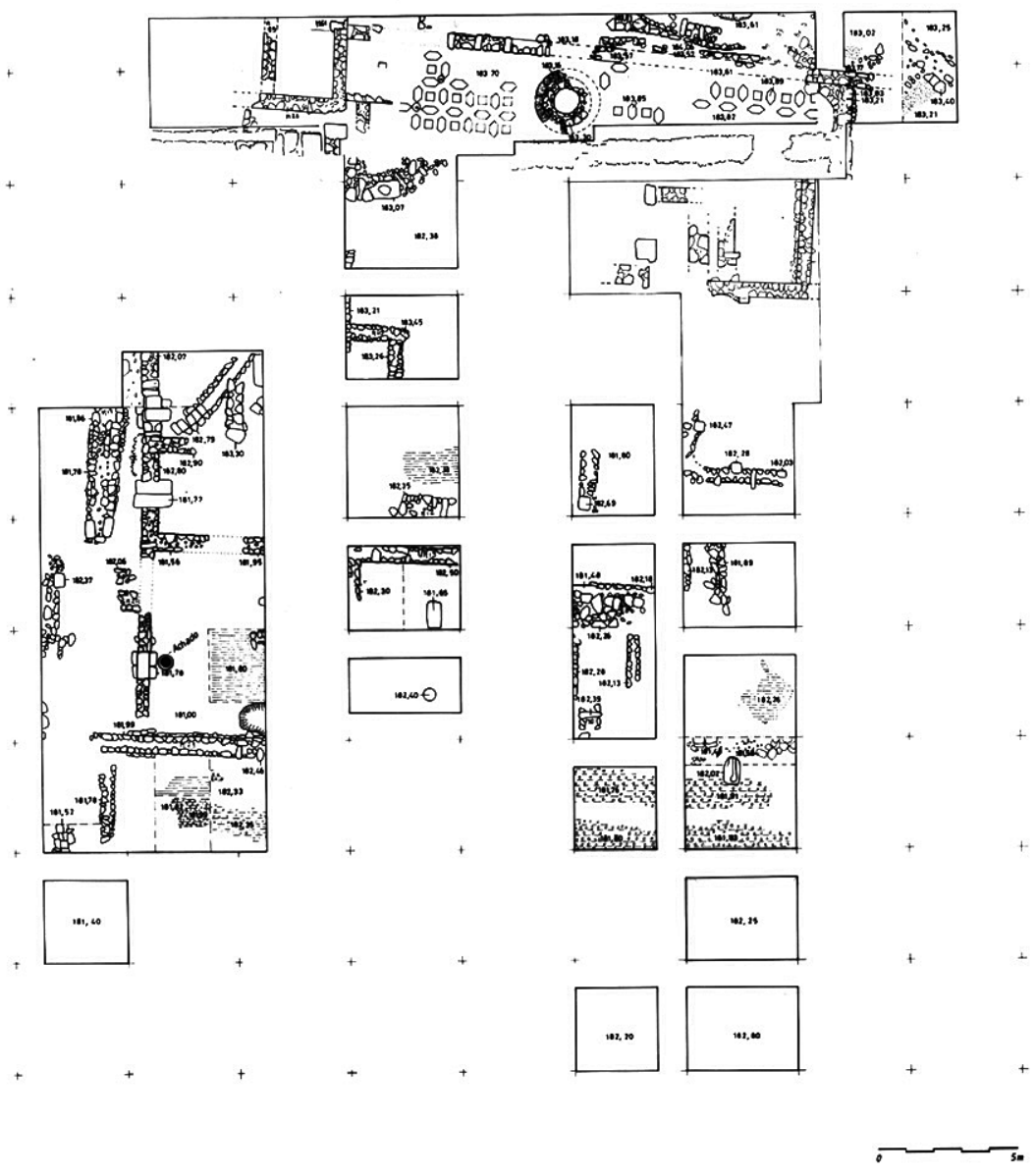

FIG. 2 


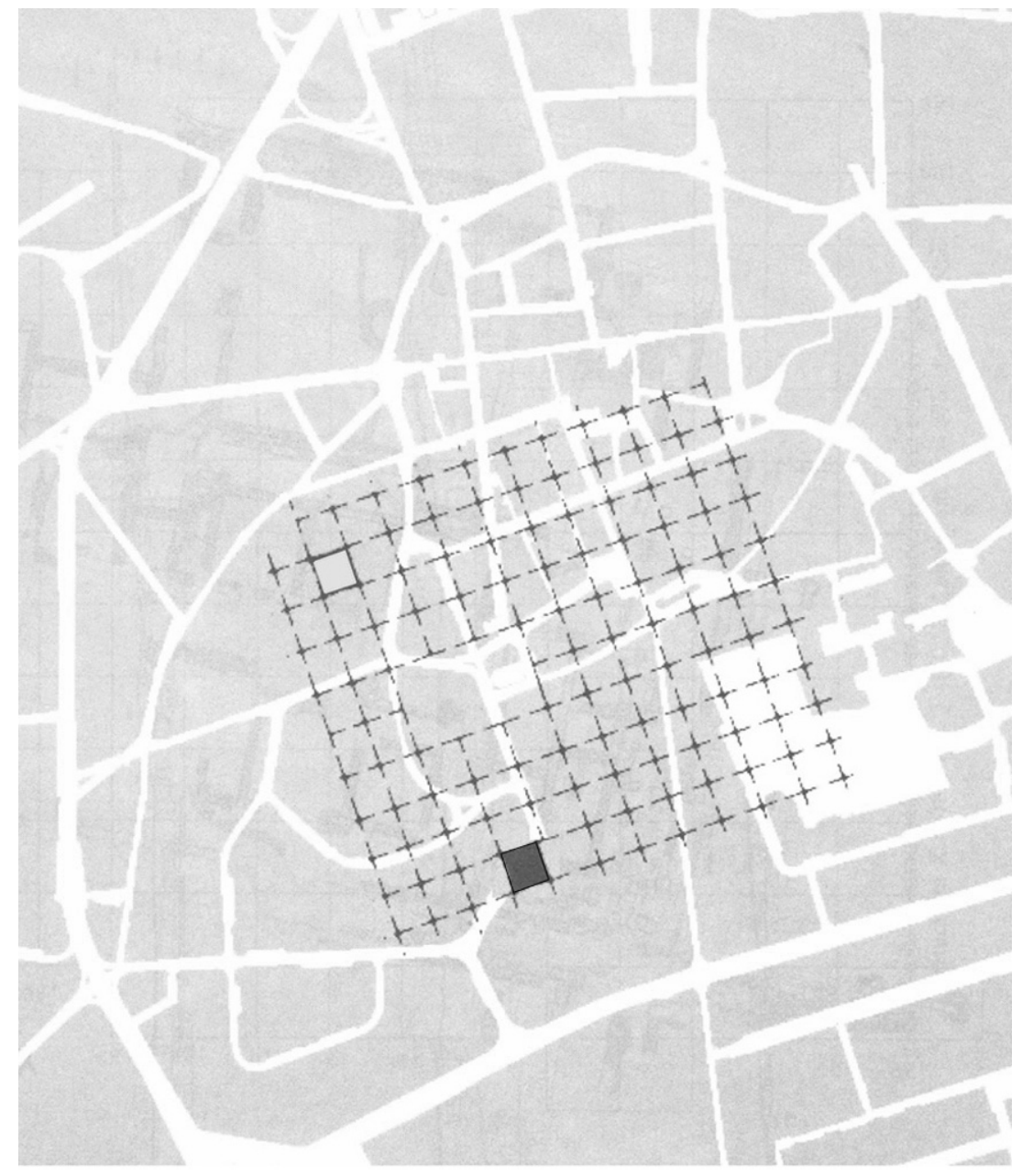

FIG. 3 


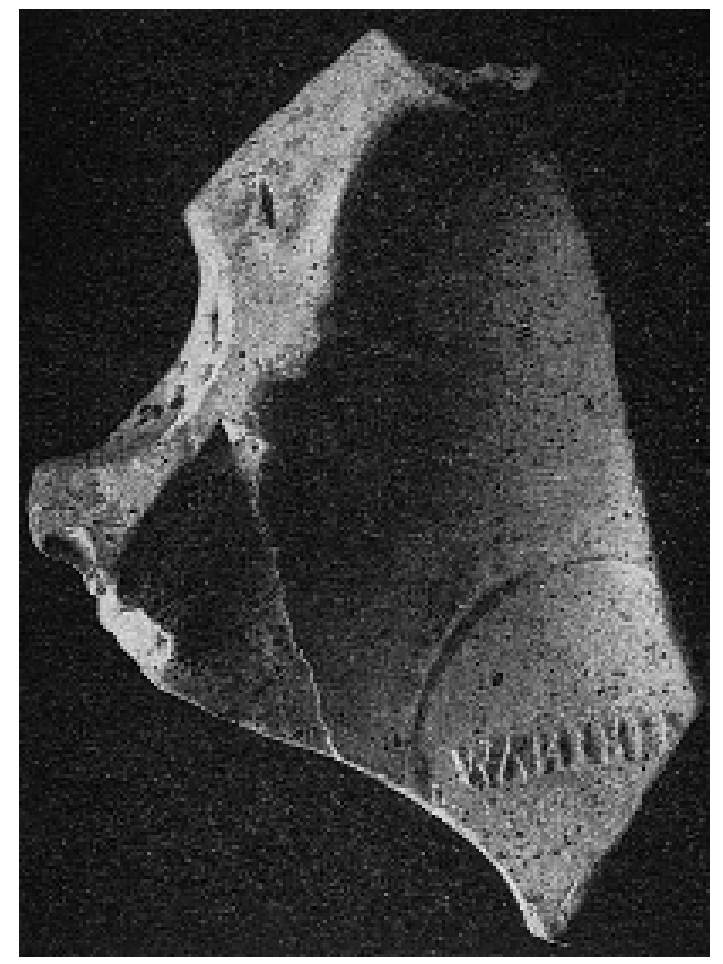

EsT. I-1

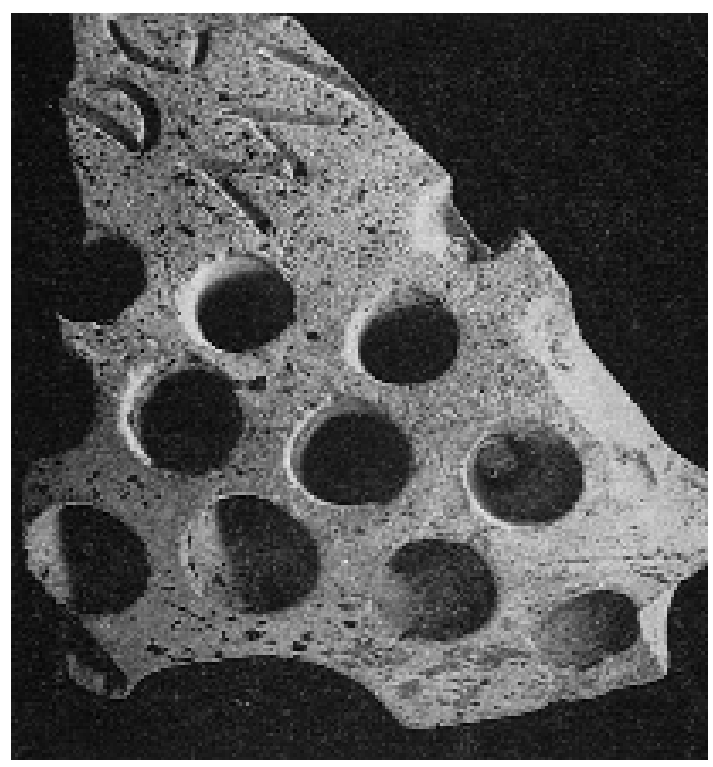

EsT. I-2 


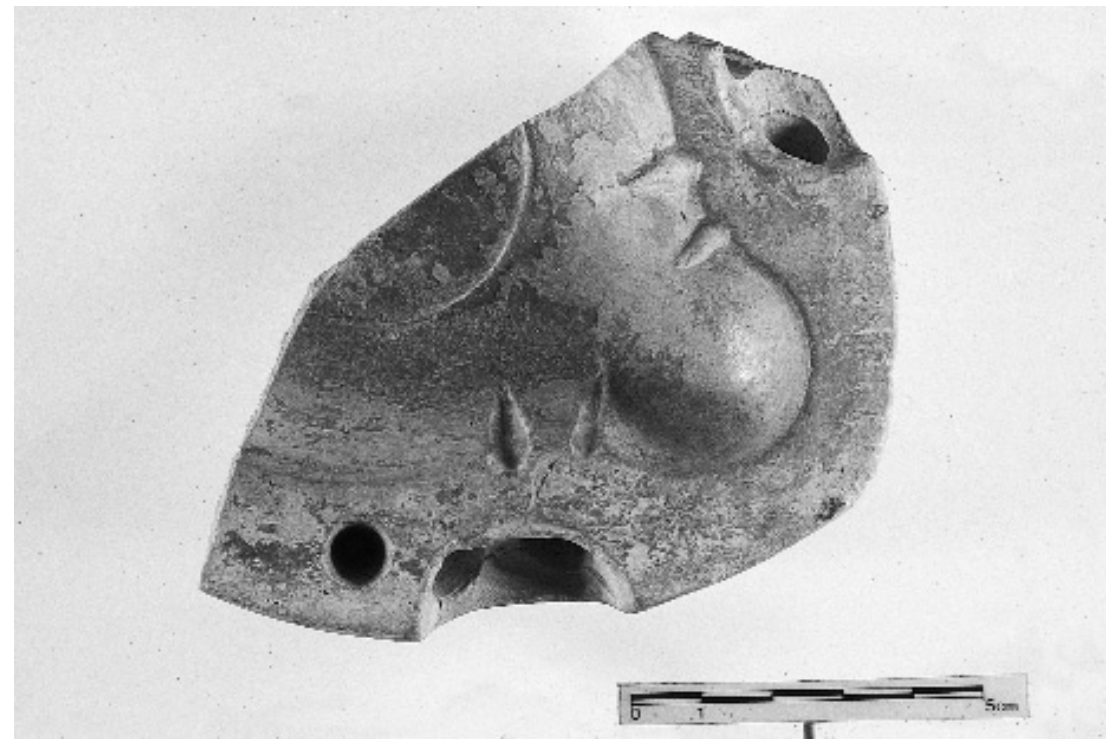

EsT. II.1

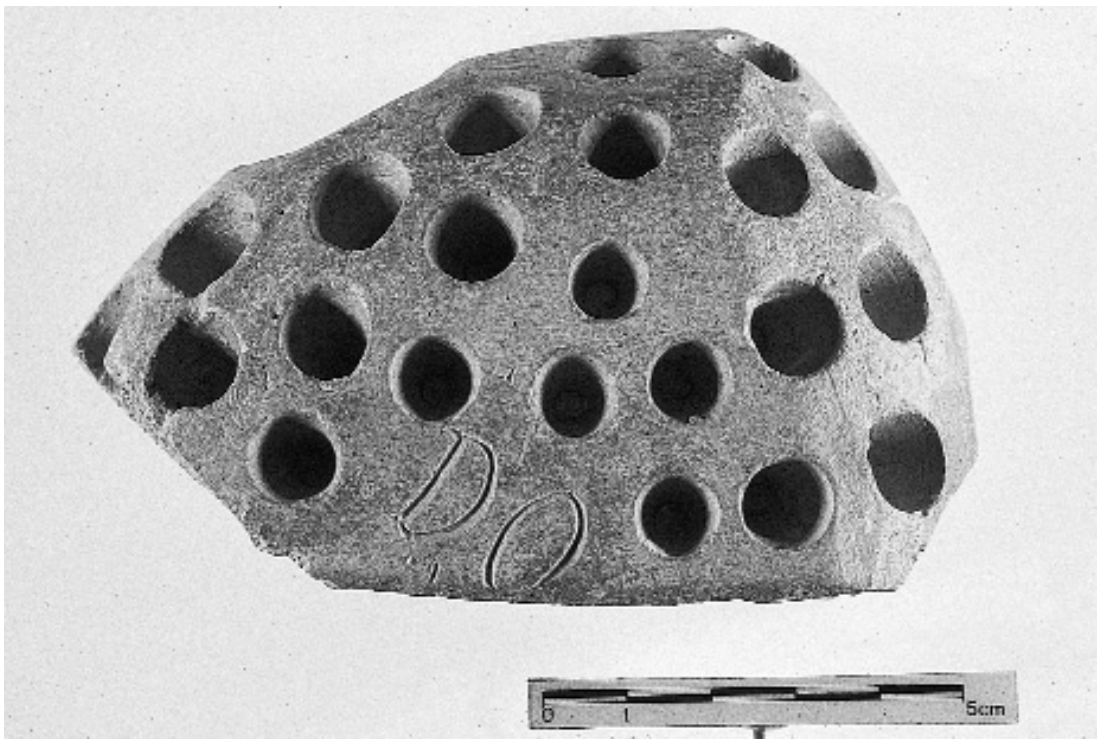

EsT. II-2 

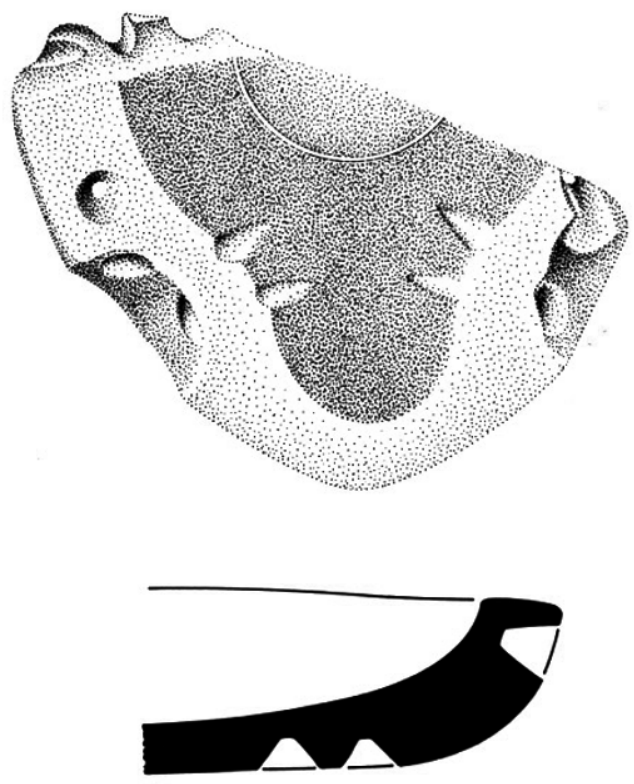

EsT. III-1

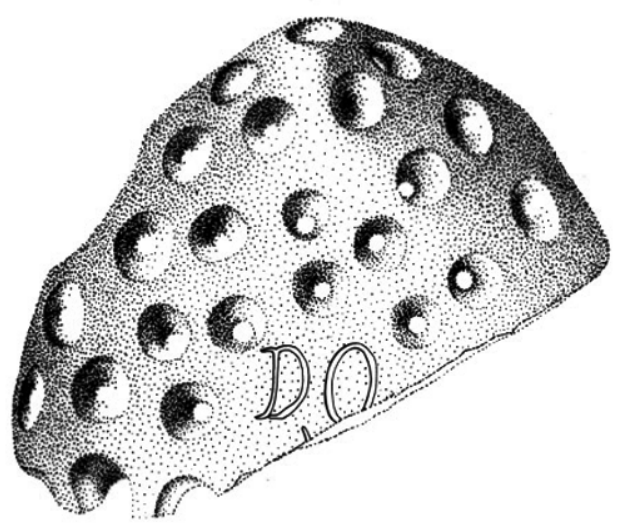

Est. III-2 


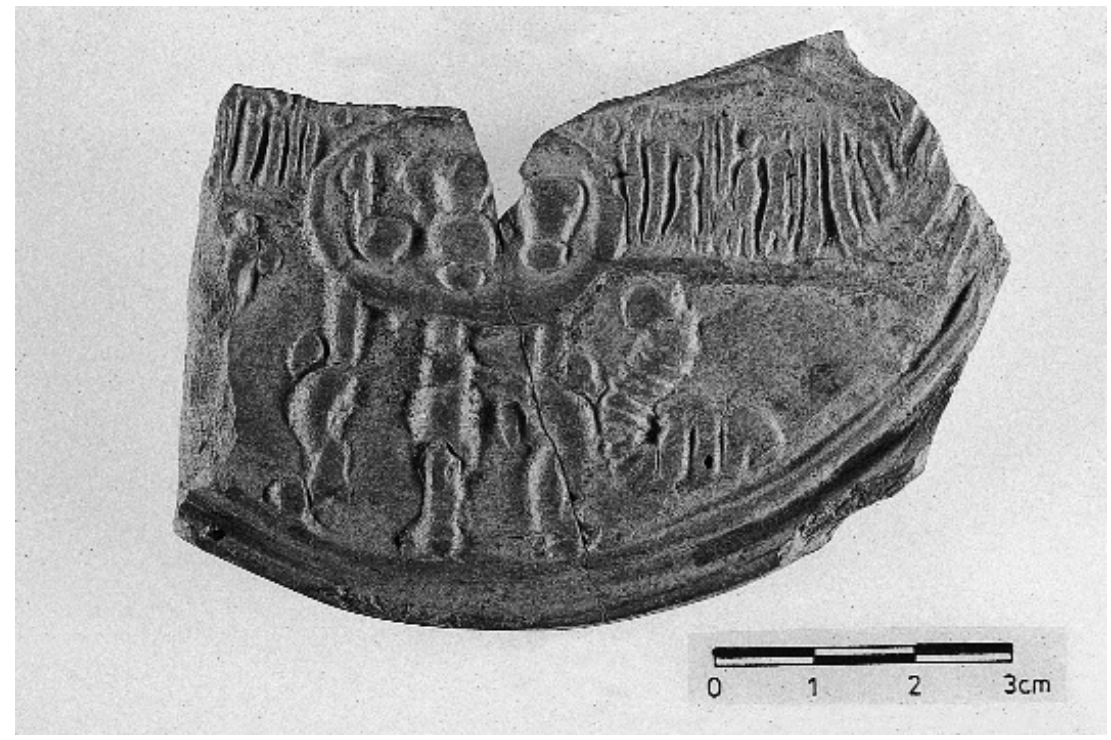

EsT. IV-1

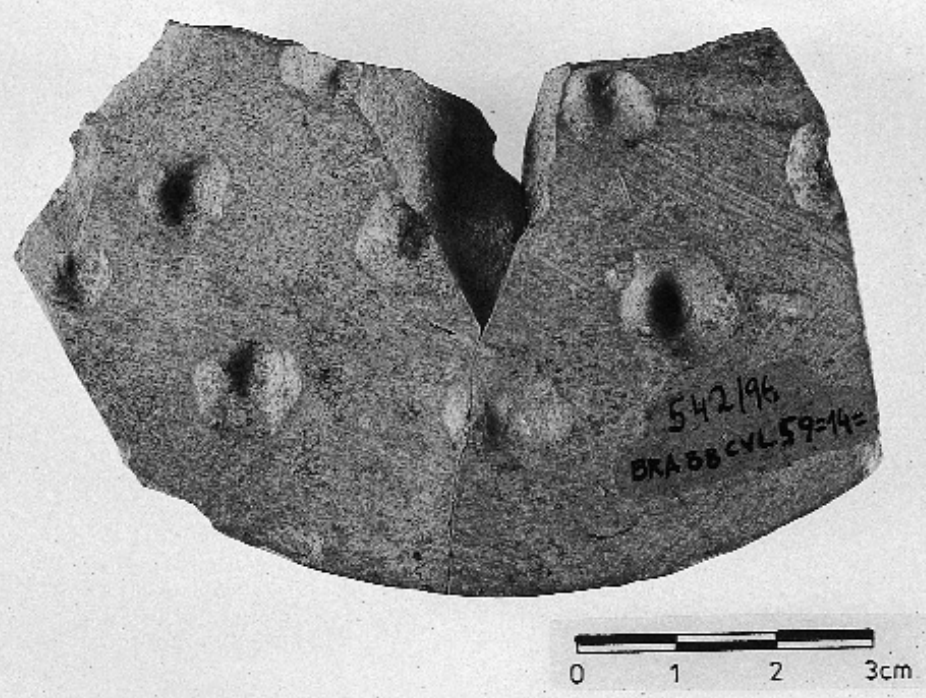

EsT. IV-2 


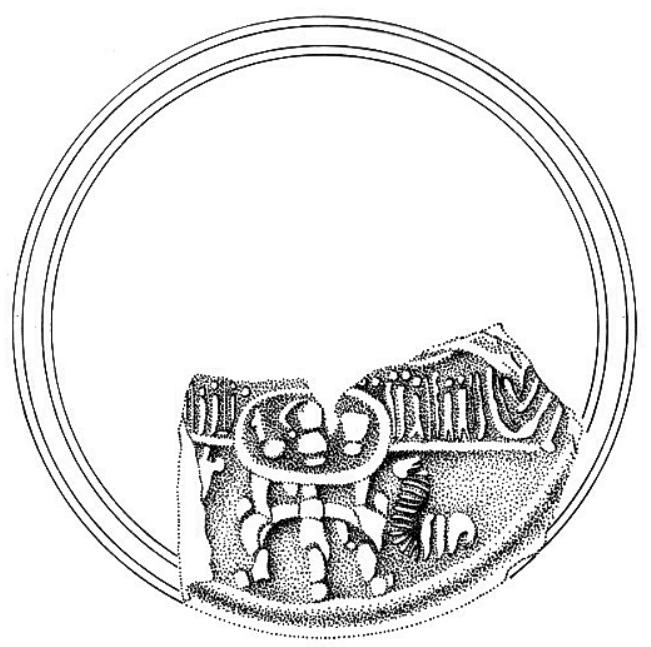

EsT. V-1
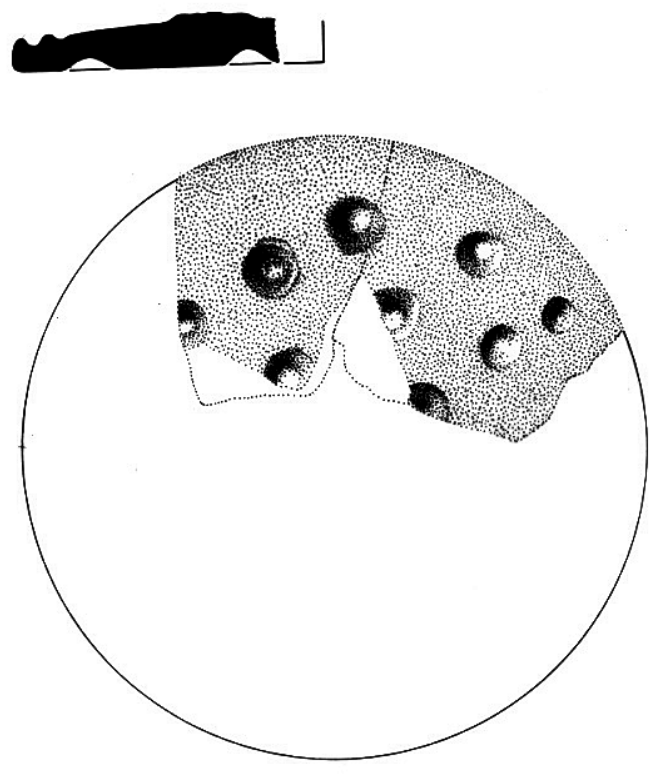

EsT. V-2 


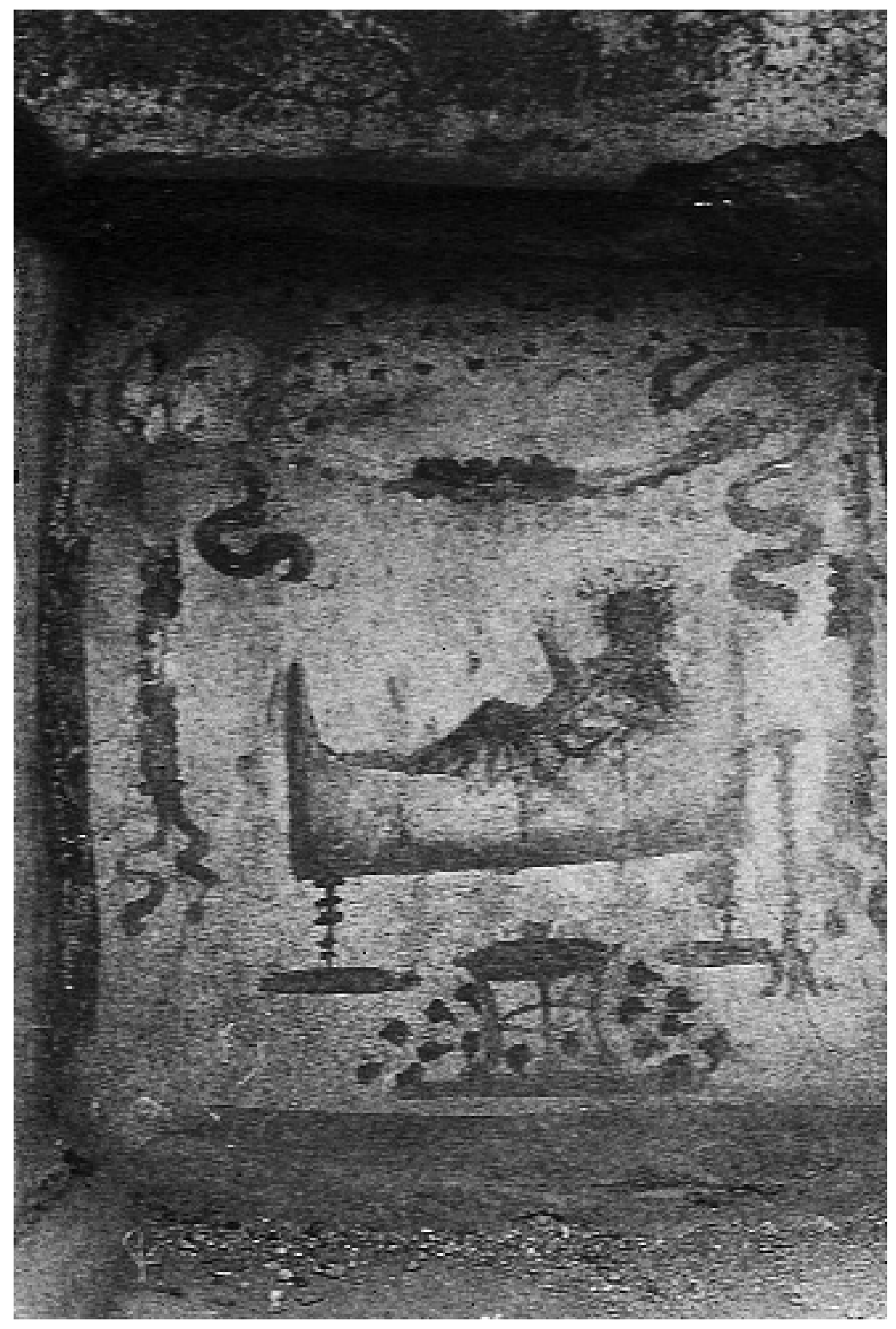




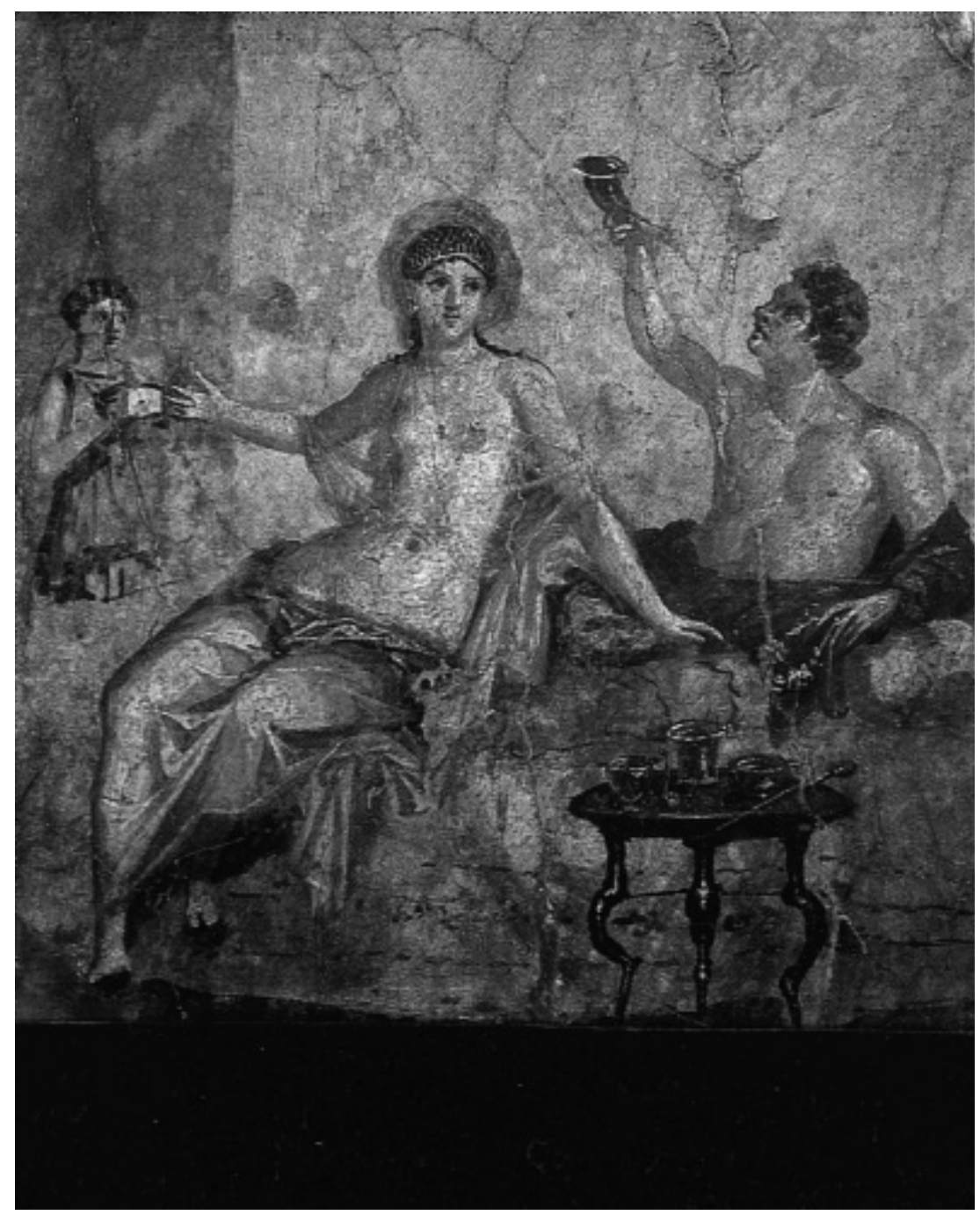

EST. VII 


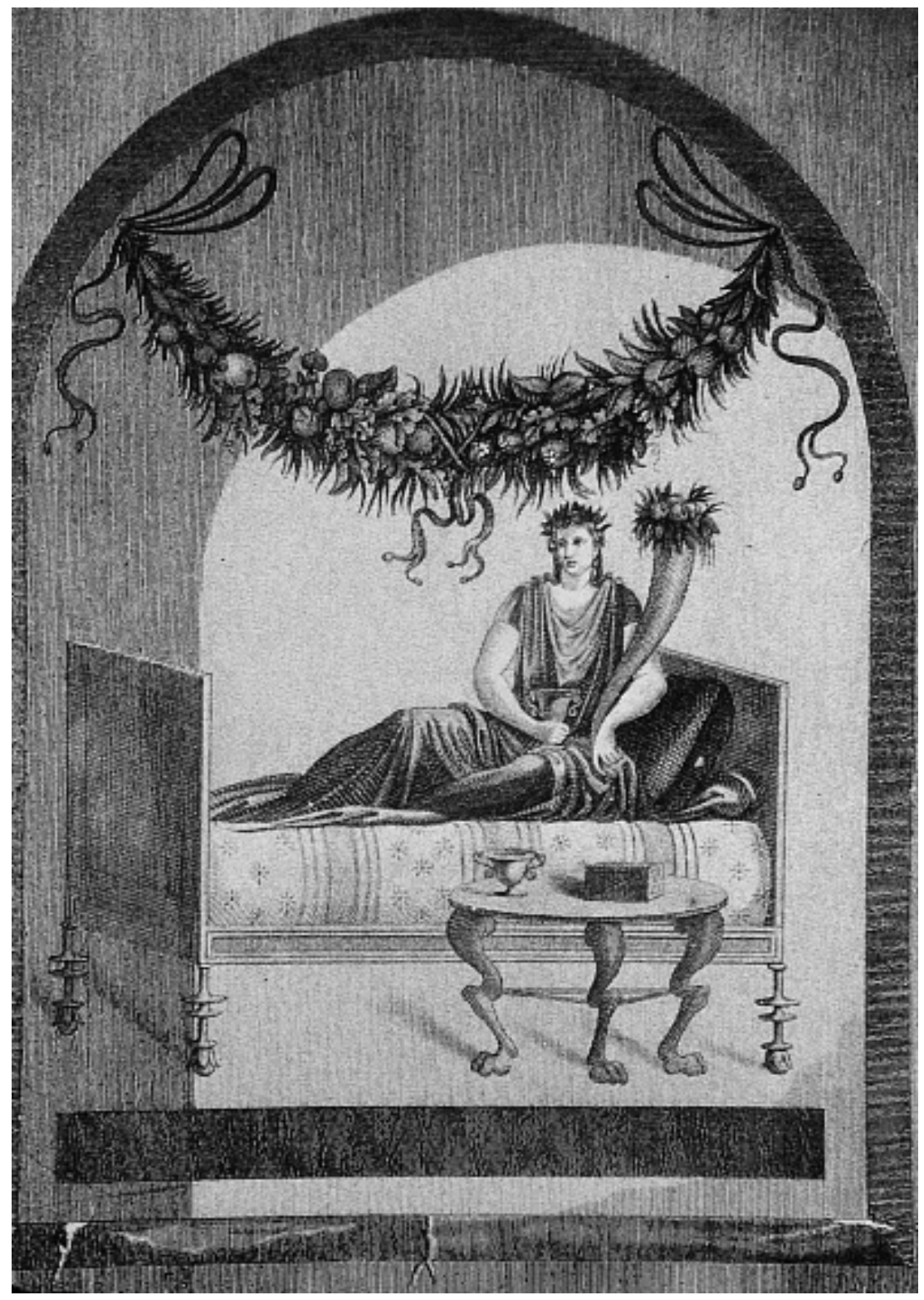

Est. VIII 